\title{
FAKTOR PENGLIBATAN REMAJA DALAM SALAH LAKU SEKSUAL: KAJIAN TERHADAP REMAJA HAMIL LUAR NIKAH DI PUSAT PEMULIHAN AKHLAK NEGERI SELANGOR
}

\author{
Mariam Abd. Majid, Nurul Zafirah Azman \& Nurul Izzah Mohd Yani
}

Faculty of Islamic Civilizations Studies, International Islamic University College Selangor (KUIS) 43000, Kajang, Malaysia.

Corresponding Author: Mariam Binti Abd. Majid. Department of Dakwah and Usuluddin, Faculty of Islamic Civilizations Studies, Kolej Universiti Islam Antarabangsa Selangor (KUIS) 43000, Kajang, Malaysia. Tel (+60) 193501617. Email: mariam@kuis.edu.my

\begin{abstract}
ABSTRAK
Generasi remaja pada hari ini merupakan modal insan negara pada masa akan datang. Peranan mencorak kepimpinan dan pembangunan negara pada masa hadapan bakal dilaksanakan oleh mereka. Namun, pendedahan berita pelbagai isu berkaitan keterlibatan remaja dalam gejala sosial yang berlaku dalam negara mencetus keadaan yang sangat membimbangkan antaranya peningkatan kes hamil tanpa nikah golongan remaja. Statistik Kementerian Kesihatan Malaysia mencatatkan sebanyak 79,302 kes remaja bawah 18 tahun hamil tanpa nikah dalam tempoh lima (5) tahun iaitu bermula dari tahun 2012-2016. Artikel ini bertujuan mengemukakan faktor-faktor penglibatan remaja dalam salah laku seksual sehingga hamil tanpa nikah. Kajian ini berbentuk kualitatif dengan reka bentuk kajian kes. Data kajian diperolehi menerusi kaedah temubual separa struktur terhadap seorang pentadbir, seorang warden di Pusat Pemulihan Akhlak di Negeri Selangor serta empat orang remaja yang hamil tanpa nikah. Кеsemиa informen kajian dipilih melalui kaedah persampelan bertujuan. Transkripsi temubual dianalisis untuk pembentukan tema dan sub tema. Dapatan kajian mendapati bahawa antara faktor penglibatan remaja dalam salah laku seksual ialah kerana percintaan dan kerelaan sendiri, mangsa rogol, menonton video dan filem porno, kelemahan institusi keluarga, konflik dalam keluarga, kejahilan dan pengabaian amalan beragama, pengaruh rakan sebaya, pengambilan pil khayal dan penglibatan dalam perlumbaan haram. Diharapkan dapatan ini dapat membantu semua pihak dalam usaha membendung gejala ini daripada terus meningkat.
\end{abstract}

Kata kunci: Faktor; Penglibatan; Remaja; Salah Laku Seksual; Hamil Tanpa Nikah; Pusat Pemulihan Akhlak Negeri Selangor 


\title{
(TEENAGERS' INVOLVEMENT FACTOR IN SEXUAL MISCONDUCT: A STUDY ON TEENAGERS' PREMARITAL PREGNANCY IN SELANGOR STATE MORAL REHABILITATION CENTRE)
}

\begin{abstract}
The young generation today is deemed as the human capital for the country in the future. This generation would be responsible for implementing and shaping the country's leadership and development. Nevertheless, the issues relating to teenagers' involvement in social problems in the country have set a concern, especially on the escalating number of premarital pregnancies among teenagers. Statistics from the Ministry of Health have shown 79,302 cases involving premarital pregnancies among teenagers below 18 years of age within five years from 2012 to 2016. This qualitative case study research aims to bring forth the main factors of teenagers' involvement in sexual misconduct, which has led to premarital pregnancies. The findings were obtained through a partially structured interview method with an administrator, a warden from Selangor Rehabilitation Centre, and four teenagers involved in sexual misconduct. All informants were selected using a purposive sampling method. The interview transcription was analyzed to structure the themes and sub-themes of the data. The overall findings found that the main factors for teenagers' involvement in sexual misconduct were due to several causes: love, voluntarily act, rape, pornographic film and video, weakness in family institutions, family conflicts, ignorance, and weak religious practice, peer influence, drug addiction and involvement in illegal racing. The outcome from this research is hoped to assist all parties in curbing this problem related to sexual misconduct and premarital pregnancies among teenagers in this country.
\end{abstract}

Keywords: Factor; Involvement; Teenagers; Sexual Misconduct; Premarital Pregnancy; Selangor Moral Rehabilitation Centre

\section{Pendahuluan}

Pengertian hamil tanpa nikah ialah mengandung sebelum berkahwin menerusi hubungan seks di antara dua pasangan tanpa suatu ikatan yang sah (Alavi, Nen, Ibrahim, Akhir, Mohamad, \& Nordin, 2012). Sub-seksyen (3), Enakmen Jenayah Syariah Negeri Selangor mendefinisikan hamil luar nikah iaitu seorang perempuan yang melahirkan anak yang sempurna sifatnya dalam tempoh yang kurang daripada enam bulan qamariah dari tarikh pernikahan

http://www2.esyariah.gov.my/esyariah/mal/portalv1/enakmen/State_Enact_Ori.nsf/100ae747 c72508e748256faa00188094/7b9650d84cbe7ea048257057000254e8? OpenDocument.

Hubungan seks berkaitan boleh berlaku sama ada secara sukarela, menjadi mangsa rogol atau sumbang mahram (Kementerian Kesihatan Malaysia, 2014). Kehamilan luar nikah dalam kalangan remaja adalah merujuk kepada remaja di bawah umur yang hamil tanpa ikatan yang sah (Sarnon, et. al. 2013). Remaja hamil luar nikah tergolong dalam kalangan yang umur di 
antara 13 hingga 18 tahun (Alavi, Nen, Ibrahim, Akhir, Mohamad, \& Nordin, 2012). Berdasarkan ini, hamil tanpa nikah atau hamil luar nikah adalah keadaan seorang wanita sama ada muda atau tua menghamilkan anak apabila terjadinya hubungan kelamin sedangkan dia bukan dalam perkahwinan yang sah.

Generasi remaja zaman ini adalah aset penting bagi negara pada masa hadapan. Golongan remaja ini bakal menerajui kepimpinan serta pemerintahan negara, menjadi tenaga yang bakal memajukan serta memelihara kedaulatan negara. Peranan remaja sangat penting dalam pembangunan sosial, budaya, politik, sukan dan ekonomi negara. Keprihatinan terhadap usaha pengukuhan generasi remaja sangat penting diberi perhatian kerana hanya golongan remaja yang kuat mental dan fizikalnya yang mampu menyumbang kepada pembangunan negara (http://dwnsiswa.dbp.my/wordpress/?m=201706).

Namun, fenomena yang berlaku dalam masyarakat akhir akhir ini adalah sangat membimbangkan. Penglibatan golongan remaja sering dikaitkan dengan pelbagai isu sosial kritikal yang berlaku dalam negara antaranya kehamilan tanpa nikah dan pembuangan bayi yang menjadi fokus artikel ini. Mohd. Fauzi \& Mohd. Khairul Naim (2012), menjelaskan bahawa gejala seks bebas, pengguguran kandungan, kelahiran anak luar nikah, dan pembuangan bayi dalam kalangan remaja hari ini bukan lagi menjadi suatu perkara asing dalam masyarakat. Realitinya, pada masa kini, mereka menerima perlakuan intim seperti berpeluk, bercium dan hubungan seks antara pasangan kekasih sebagai suatu gaya hidup yang normal. Kajian mendapati bahawa 60-70 peratus pelajar sekolah rendah yang berumur di antara 9-12 tahun mengetahui mengenai seks dan berminat untuk mengetahui lebih lanjut melalui bahan-bahan yang lucah. Kajian ini menunjukkan tahap yang serius berkaitan penglibatan golongan remaja hari ini dalam salah laku seksual. Sehubungan itu, artikel ini bertujuan membincangkan berkaitan apakah antara faktor-faktor penglibatan golongan remaja dalam salah laku seksual sehingga menjurus terhadap gejala yang lebih serius iaitu gejala hamil tanpa nikah.

\section{Sorotan Literatur}

Portal berita UKM pada Jun 2010 melaporkan bahawa Perangkaan Jabatan Pendaftaran Negara tahun 2000 hingga Julai 2008 mencatatkan lebih 257,000 sijil kelahiran didaftarkan tanpa catatan nama bapa. Ini bererti secara purata 2,500 kes anak luar nikah direkodkan setiap bulan atau hampir 84 kes setiap hari. Pecahan kes kelahiran luar nikah mengikut negeri antara tahun 2000 hingga 2008 menunjukkan 70,430 anak luar nikah didaftarkan. Negeri Selangor mencatatkan bilangan paling tinggi iaitu 12,836 orang bayi, diikuti Perak $(9,788)$, Kuala Lumpur (9,439), Sabah (8,435), Negeri Sembilan (4,108) berbanding Sarawak (617) manakala Terengganu 574 orang sahaja. Pendaftaran mengikut etnik pula menunjukkan etnik Melayu serta Bumiputera Sabah dan Sarawak adalah paling tinggi iaitu 20,949 orang bayi, India 19,581 dan Cina 18,111. Pecahan mengikut agama adalah 30,978 Islam, 18,085 Hindu, 17,236 Buddha dan Kristian 3,395 orang (Alavi, Nen, Ibrahim, Akhir, Mohamad, \& Nordin, 2012).

Pada tahun 2012, Hospital Tengku Ampuan Rahimah (HTAR), Klang merekodkan kira-kira 12,000 kes kelahiran anak luar nikah dan direkodkan bahawa remaja termuda yang melahirkan anak di hospital tersebut berusia 12 tahun. Selain itu, ianya turut berlaku di enam buah hospital pakar lain di sekitar Negeri Selangor. Pihak hospital menguruskan sekurangkurangnya satu kes remaja hamil luar nikah setiap hari dan bilangan tertinggi yang pernah dicatatkan adalah 14 kes sehari melibatkan remaja pada tahun yang sama (Mstar Online, 2013). 
Angka ini menunjukkan berlakunya peningkatan kes penzinaan dan hubungan seks terlarang dalam kalangan remaja. Keadaan menjadi semakin parah apabila golongan remaja semakin hanyut dengan aktiviti maksiat yang menyebabkan mereka rosak dan hilang hala tuju dalam kehidupan. Laporan kajian oleh Durex \& Durex, mencatatkan Malaysia sebagai sebuah negara yang mengamalkan seks luar nikah dalam kalangan remaja. Pada purata 62 kali setahun (kajian 2003) dan 86 kali setahun (kajian 2004) berbanding Jepun yang hanya 37 kali setahun (2001). Remaja perempuan turut direkodkan kehilangan dara pada usia muda iaitu ketika berumur dalam lingkungan 20 tahun (kajian 2001) dan ketika berumur 19 tahun, iaitu kajian pada 2004 (www.jais.gov.my/article/anak-zina-generasi-masa-depan-malaysia). Sebanyak 18,000 kes remaja hamil di Malaysia dilaporkan pada setiap tahun dan mendapatkan rawatan di klinik kesihatan kerajaan. Daripada jumlah tersebut, kira-kira 25 peratus atau 4,500 kes membabitkan remaja hamil luar nikah. Secara purata pula, terdapat 1,500 kes remaja hamil berlaku pada setiap bulan dan dianggarkan 50 kes sehari di seluruh negara. Berdasarkan kaji selidik Kesihatan Pelajar Berasaskan Sekolah Global (Global SchoolBased Student Health Survey) kendalian Kementerian Kesihatan pada tahun 2012 pula, sebanyak 50.4 peratus remaja mengakui sudah mula melakukan hubungan seks kali pertama sebelum usia mencecah14 tahun (BH Online, 2015).

Jabatan Kebajikan Masyarakat Malaysia (JKMM) melaporkan jumlah kelahiran anak tak sah taraf di institusi kendalian JKMM berjumlah 803 kes semenjak 2010 hingga 2013 (https://www.dosm.gov.my/v1/uploads/files/4_Portal\%20Content/1_About\%20us/7_Annual

Report/Laporan_Tahunan_2014_DOSM.pdf). Jabatan Pendaftaran Negara turut mendedahkan jumlah pendaftaran anak tak sah taraf dalam tempoh sepuluh tahun iaitu dari tahun 2005 sehingga tahun 2015 sebanyak 532,158 orang. Fenomena ini memberi gambaran bahawa gejala zina dan hubungan seks luar nikah dalam kalangan remaja di negara pada hari ini berada pada tahap kritikal dengan peningkatan jumlah kes yang sangat membimbangkan.

Kajian Pakianathan (2016) mendapati bahawa remaja yang terlibat dengan masalah sosial mempunyai keinginan yang tinggi untuk mencuba sesuatu yang baru serta sentiasa menginginkan kebebasan dalam setiap perkara yang dilakukan. Data yang direkod daripada Pertubuhan Kesihatan Sedunia (WHO) bermula daripada 2005 hingga 2011 menunjukkan bahawa Malaysia menduduki tempat keempat daripada 10 negara dalam kes kehamilan remaja berusia antara 15 hingga 19 tahun (My Metro, 2015). Kajian Ahmadian, Hamsan, Abdullah, Samah dan Noor (2014) terhadap 25 orang remaja perempuan luar bandar mendapati 52 peratus responden mengakui melakukan hubungan kali pertama seawall usia 14 tahun. Statistik hasil kaji selidik Global Kesihatan Pelajar Sekolah (GSHS) dan Lembaga Penduduk Dan Pembangunan Keluarga Negara (LPPKN) melaporkan bahawa kadar aktiviti seksual dalam kalangan remaja berusia 13 hingga 17 tahun di negara ini meningkat daripada 0.9\% pada tahun 1994 kepada 8.3\% pada tahun 2012 (My Metro, 2015). Pertubuhan Kesihatan Sedunia (WHO) pula merekodkan bermula 2005 hingga 2011 menunjukkan Malaysia menduduki tempat keempat daripada 10 negara berkaitan kehamilan remaja berusia antara 15 hingga 19 tahun (Azizan, Ismail, Dimon, \& Mohd Jabar, 2015). Berdasarkan statistik Jabatan Pendaftaran Negara, seramai 4,992 anak tidak sah taraf telah dilahirkan ibu berusia 18 tahun ke bawah pada 2017. Bilangan anak tidak sah taraf yang dilahirkan ibu berusia bawah 18 tahun sehingga Jun 2018 dicatatkan adalah seramai 1,664 orang manakala sebanyak 120 kes buang bayi yang telah direkodkan sepanjang tahun 2017 (Bernama, 2018).

Pelbagai faktor diperolehi daripada kajian-kajian lepas berkaitan penglibatan golongan remaja dalam salah laku seksual hamil tanpa nikah. Faktor-faktor tersebut boleh dikaitkan dengan aktiviti secara rela atau boleh juga dikatakan secara paksa apabila mangsa diperkosa dan dinodai untuk memuaskan nafsu para pelaku yang tidak bermoral dan berakhlak (Saim, 2013). Antara kes kehamilan tanpa nikah yang berlaku dengan paksaan 
dilaporkan di Papar pada tahun 2017, melibatkan dua orang saudara lelaki yang memperkosa adik perempuan mereka yang beumur 17 tahun. Kejadian ini berlaku di kediaman keluarga adik-beradik tersebut pada pukul 2 pagi (Rafiqah Dahali, 2018). Bahagian Siasatan Jenayah Ibu Pejabat Polis Daerah (IPD) Bintulu melaporkan satu kes kehamilan tanpa nikah yang berlaku ekoran perbuatan seorang bapa berusia 46 tahun yang telah merogol anak tirinya sehingga melahirkan bayi. Remaja malang itu mendakwa dia menjadi mangsa bapa tirinya untuk melepaskan nafsu sejak berusia sembilan tahun namun berdiam diri daripada ahli keluarga yang lain. Rahsia remaja terbabit terbongkar selepas mengalami pendarahan teruk dan pemeriksaan doktor mendapati dia baru melahirkan anak tetapi telah membuang bayi itu ke dalam tong sampah (https://www.hmetro.com.my/utama/2017/12/296866/update-bapatiri-durjana-ditahan). Ketua Penolong Pengarah Bahagian Siasatan Seksual, Wanita dan Kanak-kanak, Jabatan Siasatan Jenayah Bukit Aman, Asisten Komisioner Ong Chin Lan, menjelaskan bahawa hasil siasatan yang dilakukan terhadap kes rogol yang diterima, polis mendapati lebih 60 peratus kes remaja bawah umur melakukan salah laku seks dengan kerelaan sendiri bukan secara terpaksa. Manakala hanya 40 peratus sahaja yang benar-benar dipaksa atau dirogol. Tindakan membuat laporan dan mendakwa dirogol dibuat apabila kegiatan tidak bermoral terbongkar dan diketahui keluarga (Utusan Online, 2016). Mengikut kajian Abdullah, Ghani, Akil, \& Faudzi (2014), kebanyakan kes kehamilan remaja antara umur 15 hingga 17 tahun adalah hasil hubungan seks yang dilakukan bersama pasangan yang dikenali termasuk teman lelaki.

Bilangan kes yang telah dinyatakan ini adalah sangat membimbangkan dan jika terus berleluasa, ianya bakal memberi impak yang tidak baik kepada golongan remaja yang terlibat, keluarga, masyarakat dan masa hadapan negara. Selain itu, remaja yang hamil tanpa nikah ini berisiko tinggi menghadapi masalah mental seperti kemurungan, tekanan dan stres untuk menjadi ibubapa. Ini ditambah lagi apabila ianya kurang sokongan daripada keluarga dan masyarakat ianya sudah pasti boleh membawa remaja ini kepada risiko kemurungan, membuat keputusan yang tidak tepat dan masalah penyalahgunaan dadah (Wan Fadhilah Wan Ismail, 2011). Selain daripada itu, sebahagian besar mangsa serangan seksual mengalami PTSD (Post-Traumatic Stress Disoder). PTSD merupakan sindrom merasa cemas, konflik emosi, mengingati masa lalu yang sangat pedih setelah mengalami tekanan fizikal dan emosi yang di luar ketahanan orang biasa. PTSD sering terjadi kepada mangsa yang mengalami insiden traumatik tidak terkecuali mangsa kekerasan seksual. Mangsa memerlukan proses pemulihan daripada PTSD agar dapat meningkatkan kualiti hidup dan tidak terus menyesali kisah masa lalu yang menyebabkan trauma itu. Usaha pemulihan yang dilaksanakan berupaya membantu mangsa (Pauzi, Saim, Sarnon, \& Kamaluddin, 2016). Meskipun begitu, penyembuhan daripada PTSD tidak bermaksud mangsa boleh melupai kejadian yang telah berlaku terhadap mangsa (Illenia \& Handadari, 2011). Selain mengalami masalah mental, kehamilan luar nikah dikatakan antara masalah yang paling ditakuti jika berlaku pada waktu usia remaja kerana implikasinya secara tidak langsung mendorong kepada berlakunya kes pengguguran, pembuangan dan perdagangan bayi yang tidak berdosa (Magdalena, 2010). Sungguhpun, gejala hamil tanpa nikah diketahui adalah suatu keadaan yang digeruni para remaja wanita tetapi jalan untuk terjebak dalam permasalahan tersebut merupakan suatu perkara yang sukar dielakkan apabila mereka terdedah dan bergelumang dengan aktiviti yang tidak baik sama ada secara paksa atau rela. Ramai dalam kalangan remaja yang terjebak disebabkan pelbagai faktor dan masalah yang melingkungi mereka seperti keluarga yang berpecah pelah, sejarah penderaan seksual daripada ahli keluarga, ketagihan pornografi dan terlibat dalam aktiviti seksual luar nikah (Zakaria \& Zulkifli, 2017). Keprihatinan dan usaha semua pihak dalam membendung gejala hamil tanpa nikah dalam kalangan remaja ini sangat diharapkan agar ianya dapat dibendung daripada terus meningkat. 


\section{Metodologi Kajian}

Kajian ini kualitatif dengan reka bentuk kajian kes ini dilaksanakan menggunakan pendekatan semulajadi atau natural approach untuk memahami suatu fenomena dalam konteks yang khusus. Kajian kualitatif bersifat lapangan dilakukan bertujuan untuk menjelaskan fenomena secara mendalam dan lebih mengutamakan kualiti data dibandingkan dengan kuantiti data (Kriyantono, 2006). Kajian lapangan adalah strategi penyelidikan yang sesuai untuk meneroka bidang kajian. Tujuan dan strategi di sini untuk mengetahui secara mendalam keadaan sebenar kumpulan atau kejadian tertentu. Kajian lapangan dijalankan dalam keadaan semula jadi dan tertumpu pada konteks situasi tertentu (Masri, 2005).

Dapatan bagi kajian yang dilaporkan dalam penulisan artikel ini, diperolehi menerusi kaedah temubual separa struktur terhadap enam orang informen iaitu seorang pentadbir (P1) dan seorang warden (P2) di Pusat Pemulihan Akhlak iaitu sebuah rumah perlindungan yang menempatkan remaja-remaja perempuan yang hamil tanpa nikah di Negeri Selangor serta empat orang remaja (R1 hingga R4) yang hamil tanpa nikah. Kesemua informen kajian dipilih melalui kaedah persampelan bertujuan seperti jadual 1 berikut:

Jadual 1. Pemilihan Infomen Secara Persampelan Bertujuan

\begin{tabular}{ccc}
\hline Bilangan & Informen & Kriteria \\
\hline P1 & Pentadbir & Bertugas di Pusat Pemulihan Akhlak \\
P2 & Warden & Bertugas di Pusat Pemulihan Akhlak \\
R1-R4 & Remaja & Hamil Tanpa Nikah \\
\hline
\end{tabular}

Teknik pemilihan sampel dilakukan secara bertujuan dengan memilih informan daripada kumpulan homogenous tetapi dapat memberikan maklumat yang pelbagai. Informan bagi kajian ini dipilih berdasarkan kriteria keperluan kajian. Bagi menjangkakan soalansoalan yang dapat memberikan maklumat yang lebih baik, transkrip temu bual yang dirintiskan sebelum temu bual sebenar diambil kira. Pengkaji memilih dua orang responden yang mempunyai ciri yang sama dengan sampel kajian sebenar untuk ditemu bual bagi melihat kesesuaian soalan. Berdasarkan kajian rintis terdapat dua soalan dipermudahkan dan diperbaiki. Soalan yang diperbaiki digunakan dalam kajian sebenar. Sebaik sahaja proses temu bual dan pengumpulan data kajian sebenar dilakukan, pengkaji melengkapkan transkripsi dan mengembalikan semula transkripsi kepada informen untuk disahkan. Setelah transkripsi disemak, informan menandatangani borang pengesahan temu bual bagi mengesahkan maklumat temu bual. Transkripsi temu bual yang disahkan dianalisis menggunakan tema dan sub tema. Tema dan sub tema tersebut kemudiannya disahkan oleh pakar melalui pengiraan Cohen Kappa. Seramai tiga orang pakar dilantik untuk membuat semakan tema dan sub tema dan sub tema dan sub tema. Jadual 2 di bawah merupakan senarai latar belakang pakar yang membuat persetujuan dalam pembinaan tema dan sub tema. 
Published by Faculty of Islamic Civilization Studies, KUIS

Jadual 2. Pakar dan Kepakaran Bagi Tahap Persetujuan Cohen Kappa

\begin{tabular}{cccc}
\hline Bil & Nama & Kepakaran & Tahap Persetujuan (Cohen Kappa) \\
\hline 1 & Pakar A & Psikologi & 0.94 \\
2 & Pakar B & Komunikasi & 0.92 \\
3 & Pakar C & Remaja & 0.92 \\
\hline & Keseluruhan & 0.93 \\
\hline
\end{tabular}

Tahap keseluruhan persetujuan pakar terhadap tema dan sub tema dan sub tema dan sub tema berdasarkan pengiraan Cohen Kappa adalah 0.93 dan berdasarkan kepada Jadual 3 di bawah, nilai $k=0.92$ berada pada skala sangat tinggi.

Jadual 3. Skala persetujuan Cohen Kappa

\begin{tabular}{cc}
\hline Nilai Kappa & Skala Interpretasi \\
\hline$>0.90$ & Sangat Tinggi \\
$0.70-0.89$ & Tinggi \\
$0.30-0.69$ & Sederhana \\
$<0.30$ & Rendah \\
\hline
\end{tabular}

Sumber: Jasmi, K. A. (2012)

Data-data kajian dalam artikel ini dianalisis secara transkripsi yang menghasilkan pembentukan tema-tema dalam dapatan kajian berikut;

\section{Dapatan Kajian}

Pelbagai faktor dikenalpasti menjadi faktor penglibatan remaja dalam salah laku seksual yang menyebabkan mereka hamil tanpa nikah. Berikut adalah dapatan kajian berkaitan faktorfaktor tersebut:

\subsection{Institusi Keluarga}

Kesejahteraan sesebuah keluarga dipengaruhi oleh kekuatan hubungan pasangan suami isteri dalam perkahwinan mereka (Baharudin, Hamdani, Mutalib, \& Zakaria, 2018). Kekukuhan institusi keluarga penting untuk memastikan seluruh ahli keluarga berada dalam selamat dan terbela. Berikut adalah beberapa faktor berkaitan kelemahan institusi keluarga yang dinyatakan berkaitan penglibatan remaja dalam salah laku seksual dalam kalangan remaja: 


\subsubsection{Perceraian Ibubapa}

Anak-anak daripada keluarga yang mengalami penceraian akan mengalami pelbagai emosi dan perasaan disebabkan ketiadaan ibu bapa sebagai peneraju utama dalam memastikan fungsi sebebuah keluarga berjalan dengan baik. Antara emosi-emosi yang sering dikaitkan dengan anak-anak apabila ibu bapa mereka bercerai adalah perasaan sedih, tertekan, malu, marah, benci, bersalah dan sebagainya. Emosi ini muncul ekoran tekanan yang dihadapi kerana mengalami keadaan hidup yang berbeza daripada keadaan yang sebelumnya (Zulkefli, \& Mustapha, 2017). Keadaan ini menyebabkan mereka cenderung merasa kesunyian dan rasa hilang tempat bergantung disebabkan keadaan keluarga yang bermasalah. Implikasinya, golongan remaja lebih banyak menghabiskan masa bersama rakan dan kadangkala sering melakukan aktiviti yang tidak bermoral bersama rakan-rakan. Faktor perceraian ibu bapa memberi impak terhadap kebahagiaan hidup berkeluarga terutama kepada anak-anak yang kehilangan sokongan ibubapa sepatutnya mereka perolehi. Menurut $\mathrm{P}^{1}$ katanya:

"Mengikut pengalaman sayalah sepanjang bekerja di sini, dia ikut by batch. Batch terdahulu disebabkan masalah rumah tangga, masalah keluarga. Penceraian ibu ayah...jadi sokongan ibu bapa tu kurang... lepas tu ibu bapa pula busy balik lewat malam." $\left(\mathrm{P}^{1}\right)$

Berdasarkan kenyataan, adalah disimpulkan bahawa ibu bapa yang bercerai berai memberi impak negatif terhadap perkembangan peribadi remaja kerana keluarga dan ibu bapa adalah tulang belakang yang sepatutnya memberi sokongan yang baik kepada anakanak. Keluarga yang hidup berpecah belah tidak dapat mewujudkan kasih sayang sesama ahli keluarga dan ianya boleh menyebabkan anak-anak rasa terpinggir.

\subsubsection{Kesibukan Ibubapa}

Kesibukan ibubapa merupakan antara yang turut dinyatakan sebagai faktor remaja terjebak dalam kes hamil tanpa nikah. Kesibukan ibubapa yang serius menjurus kepada pengabaian perhatian dan kasih sayang terhadap anak-anak. Informen remaja $\left(\mathrm{R}^{2}\right)$ menyatakan berkaitan keadaan yang dialami:

Ibu bapa saya sering mengabaikan saya dan adik beradik yang lain. Mereka sering menghabiskan masa mereka di pejabat. Biasanya mereka akan pergi ke pejabat pada pukul 6.30 pagi dan pulang ke rumah pada 9 malam. Masa mereka hanya di habiskan hanya di pejabat. $\left(R^{2}\right)$

Kesunyian merupakan salah satu perasaan negatif memberikan kesan terhadap kesejahteraan individu. Kajian Alavi, Nen, Ibrahim, Akhir, Mohamad dan Nordin (2012) mendapati remaja hamil luar nikah tidak mempunyai hubungan yang rapat dengan ibu bapa sehingga mendorong mereka terlibat dalam aktiviti seksual yang tidak sihat. Kesibukan ibu bapa dalam mengejar harta dunia, kurang komunikasi dengan anak-anak, jarang berada di rumah serta kurang sokongan sosial merupakan antara punca menyebabkan anak remaja terjebak dalam gejala kehamilan tanpa nikah. 


\subsubsection{Konflik Keluarga}

Konflik yang berlaku dalam keluarga menjadi faktor penyebab berlakunya ketidak stabilan emosi dalam kalangan ahli keluaraga khususnya anak-anak (Zulkefli \& Mustapha, 2017). Keadaan ini boleh menjurus anak remaja untuk melibatkan diri dengan perkara yang tidak berfaedah. Emosi remaja yang tidak stabil seperti marah, geram, tertekan dan dendam mendorong remaja melepaskan geram dan tekanan dengan melibatkan diri dalam gejalagejala sosial. Ini diterangkan menerusi temubual bersama $\mathrm{R}^{2}$ katanya:

Saya memberontak dengan kedua ibu bapa saya. Saya tidak akan pulang ke rumah setelah pulang dari sekolah. Waktu persekolahan akan tamat pada pukul 2 petang. Jadi saya akan ke tempat lain dahulu kerana saya tahu ibu bapa saya akan pulang ke rumah pada pukul 9 malam. Jadi saya akan menghabiskan masa saya di luar. $\left(\mathrm{RI}^{2}\right)$

Tindakan seumpama ini bukan sahaja memudaratkan diri sendiri, malahan turut memudaratkan orang lain apabila tingkah laku tersebut bertukar menjadi perlakuan gejala sosial mahupun jenayah yang agresif dan berskala besar.

\subsection{Percintaan}

Gejala remaja hamil tanpa nikah boleh berlaku apabila perbuatan zina dilakukan dengan kerelaan remaja dan pasangan yang sedang dilamun cinta (Pakianathan, 2016). Temubual bersama salah seorang warden di Pusat Pemulihan Akhlak menjelaskan bahawa kebanyakan faktor berlakunya remaja hamil tanpa nikah ialah penzinaan yang berlaku secara rela. Menurut beliau $\left(\mathrm{P}^{2}\right)$ :

\section{Aaaa... kalau yang anak luar nikah ni, kami boleh katakan kebanyakannya lah, kebanyakannya memang suka sama suka, berzina... Kalau rekod sebelum ni ada yang masuk sebab di rogol ada. Ada yang berzina pun ada. ${ }^{\left(\mathrm{P}^{2}\right)}$}

Kenyataan ini menjelaskan bahawa kebanyakan kes remaja hamil tanpa nikah berlaku kerana kerelaan melakukan penzinaan. Kenyataan P2 dikukuhkan lagi oleh wakil pengurus Pusat Pemulihan Akhlak (P1) yang menyatakan:

"Tapi macam ustaz kata tadi, suka sama suka lah, kalau kata sumbang mahram tu ada sorang je, kalau kata kena rogol pun ada sorang je.” $\left(\mathrm{P}^{1}\right)$

Penzinaan dalam kalangan remaja ini mudah apabila mereka mempunyai perasaan cinta kepada pasangan masing-masing.

\subsection{Video dan Filem Porno}

Kepesatan perkembangan alat teknologi komunikasi moden membawa sama implikasi negatif dan positif. Penyebaran dengan berleluasa penyebaran video dan filem porno. Video dan filem-filem porno diperdagangkan sehingga menjadikan industri perfileman yang sangat menguntungkan. Media massa memainkan peranan yang penting dalam pembentukan pelakuan seksual dalam kalangan remaja. Media massa merupakan suatu bahan yang sangat mudah menarik pengaruh remaja seperti tontonan video lucah, mencari teman dengan mudah, 
berlepak melalui chatting, berseronok dengan alam maya dan sebagainya memberi ruang untuk remaja bertindak dengan bebas tanpa kawalan dalam pelakuan salah laku seksual (Pakianathan, 2016). Penyebaran filem dan video porno memberi kesan negatif terhadap masyarakat khususnya golongan remaja yang dalam peringkat sedang meningkat dewasa (Opasawas, 1996). Kesan pengaruh ini dinyatakan oleh $\mathrm{R}^{1}$ :

"Ermmm, saya terlibat dalam serangan seksual fizikal ini kerana saya terjebak dengan video porno sejak berumur 14 tahun lagi. Saya mula kenal dengan video ini kerana teman lelaki saya yang menunjukkan video porno ini pada telefon bimbitnya”. $\left(R^{1}\right)$

Kenyataan ini menjelaskan bahawa tindakan remaja menonton video porno bersama pasangan menyebabkan terdorong untuk melakukan hubungan seksual sehingga berlakunya kehamilan tanpa nikah. Keadaan ini turut dinyatakan oleh R3 dalam temubual:

"Saya mula kenal dengan video porno ini kerana teman lelaki saya menunjukkan video ini pada saya. Saya pada mulanya tidak terlalu memahami video yang dipertontonkan. Namun lama kelamaan saya berasa sangat seronok. Sehinggakan pada suatu hari teman lelaki saya mengajak saya untuk melakukan adegan seperti yang ditonton di dalam video tersebut. Saya menolak ajakan teman lelaki saya, tetapi dia menerangkan pada saya bahawa tiada apa-apa yang akan berlaku, malah saya akan berseronok. Setelah berulang kali dia memujuk saya. Jadi saya ikut dan menurut." (R3)

Berdasarkan kenyataan ini mendapati bahawa tindakan pasangan remaja lelaki yang memperkenalkan video porno telah merangsang pasangan mereka untuk melakukan penzinaan. Kajian Suzana Jaafar (2005) mendapati majoriti remaja lelaki mendapat pengalaman belajar tentang seks dari majalah lucah berbanding dengan remaja perempuan yang mendapat pengalaman dari teman lelaki. Bercinta pada usia yang terlalu muda menyebabkan remaja terperangkap dalam cinta yang tidak matang. Remaja yang bercinta pada usia muda mudah terpengaruh mengikut kehendak atau permintaan teman lelaki mereka tanpa boleh berfikir dengan rasional. Menurut Muhammud (2012) faktor utama penglibatan mereka ialah pujukan teman lelaki dan inginkan keseronokan serta kemewahan dunia.

\subsection{Mangsa Rogol}

Kejadian rogol yang dilakukan terhadap remaja merupakan antara faktor yang turut dinyatakan sebagai sebab berlakunya fenomena remaja hamil tanpa nikah (Zakaria, Zakaria, Sarnon, \& Saim, 2017). Warden Pusat Pemulihan akhlak $\left(\mathrm{P}^{2}\right)$ menyatakan:

“... Kalau rekod sebelum ni ada yang masuk sebab di rogol ada. Ada yang berzina pun ada”. $\left(\mathrm{P}^{2}\right)$

Kenyataan oleh $\mathrm{P}^{2}$ di atas menjelaskan bahawa faktor penglibatan remaja dalam salah laku seksual menjadi punca mereka terjebak dengan gejala hamil tanpa nikah ekoran kisah silam yang dilalui apabila remaja menjadi mangsa terhadap kejadian rogol dan sumbang mahram. 


\subsection{Pengabaian Amalan Beragama dan Kejahilan}

Keluarga yang tidak menitik beratkan ilmu serta amalan hidup berasaskan agama menyebabkan remaja tidak memahami asas agama yang sepatutnya mereka fahami sebagai seorang beragama Islam. Keluarga yang tidak pernah menunaikan solat secara berjamaah dikenalpasti menjadi antara punca remaja terjebak dengan perbuatan tidak sihat. Luahan remaja berkaitannya diperolehi menerusi temu bual bersama $\mathrm{P}^{1}$, katanya:

"Kita ada program parenting juga. Dan kalau kita amati betul-betul sebenarnya bermula dari keluarga lah, keluarga tu solat tu macam mana? Kalau kita tanya kepada pelatih itu sendiri pun, kata mereka tidak pernah pun solat berjemaah di rumah, keluarga tu bagus je cuma solat tu. Kerohanian dalam keluarga tu tak ada." $\left(\mathrm{P}^{1}\right)$

Kenyataan di atas menerangkan bahawa sesetengah ibu bapa gagal mewujudkan sebuah keluarga yang patuh dan taat pada hukum agama terutamanya dalam pelaksanaan solat. Keluarga yang gagal mempraktikkan solat sama ada secara sendiri atau berjemaah akan menyebabkan anak-anak membesar menjadi remaja yang bermasalah. Perkara yang demikian kerana, remaja gagal memahami nilai dan hukum agama yang sebenar apabila ibu bapa tidak menasihati atau memberi peringatan. Terdapat dalam kalangan remaja yang dihantar ke Pusat Pemulihan akhlak ini tidak tahu melaksanakan sembahyang. Kenyataan wakil pengurusnya (P1) menjelaskan:

"Ok pengetahuan agama, bila ada pelatih di sini baru masuk, kita akan ada kelas atau klinik agama dengan ustazah MAIS, lepastu ustazah akan tengok dan uji diorang, uji solat, uji baca Quran. Ikutkan kalau solat tu memang basic pun diorang tidak ada. Dari segi pendidikan kat sekolah tu bagus, tapi dari segi pengetahuan agama tu kuranglah. Pengamalan agama mereka tiada”. (P1)

Berdasarkan kenyataan, adalah didapati remaja kurang menguasai pengetahuan agama berbanding pengetahuan akademik. Pengamalan beragama yang tidak diamalkan menjadi faktor menyumbang berlakunya fenomena hamil tanpa nikah dalam kalangan remaja ini. Asas pengetahuan agama terutama perkara berkaitan solat dan membaca al-Quran menjadi tunjang pembentukan akhlak dan tingkah laku yang baik. Remaja bermasalah sering mengabaikan amalan beragama dalam agama Islam. Khadijah Alavi (2012) menyatakan bahawa hampir semua kes remaja hamil tanpa nikah ini didapati tidak berpegang kepada agama sebagai landasan hidup dan mengabaikan solat walaupun telah dinasihati oleh ibu bapa. Lebih membimbangkan, ibu bapa dikenal pasti tidak mengambil tindakan jika anakanak enggan mengerjakan solat.

\subsection{Rakan Sebaya}

Rakan sebaya sangat berpengaruh kuat dalam pembentukan akhlak dan peribadi seseorang terutama golongan remaja yang banyak menghabiskan masa bersama rakan di sekolah ataupun di luar waktu sekolah jika mereka keluar bersama. Selain itu, terdapat sebahagian remaja lebih memilih untuk bersama rakan sebaya bagi mengisi kasih sayang yang kurang diberikan oleh ibu bapa. Keperluan untuk di sayangi menyebabkan individu berusaha mendapatkan kasih sayang. Rakan menjadi sebagai tempat remaja mendapatkan pengganti 
kasih sayang ibubapa atau keluaraga. Ini menyebabkan remaja lebih mudah dipengaruhi oleh rakan sebaya berbanding ibu bapa. Temubual bersama bersama $\mathrm{R}^{1}$ menjelaskan:

"Saya anggap rakan saya adalah orang yang paling memahami saya. Berbanding dengan orang lain. Orang yang sentiasa ada ketika saya susah dan senang. Jadi saya rasa, saya lebih percaya mereka." $\left(\mathrm{R}^{1}\right)$

Kenyataan ini jelas menyatakan bahawa remaja lebih memilih rakan sebaya sebagai teman untuk menemani hidupnya kerana pada mereka, ibu bapa mengabaikan dan kurang memberi kasih sayang kepada mereka. Kebiasaannya, pemilihan rakan sebaya berlaku apabila wujudnya persamaan sama ada dari aspek tingkah laku, sikap dan identiti (Ab. Aziz, 1999). Selain itu, sikap sebahagian ibu bapa yang tidak mengambil berat siapa rakan anakanak boleh menyebabkan anak-anak tersalah memilih rakan seperti memilih rakan-rakan yang terjebak dengan masalah-masalah sosial. Ini dijelaskan oleh $\mathrm{R}^{4:}$

Faktor saya terlibat di dalam serangan seksual fizikal ini apabila saya mula memasuki kelab malam. Saya mula mengenal kelab malam sejak saya berumur 15 tahun lagi. Saya terjebak dengan aktiviti ini apabila rakan baik saya mengajak saya utuk pergi ke kelab malam. Hampir setiap minggu saya dan rakan baik saya akan menghabiskan masa kami di kelab malam sehingga pukul 4 atau 5 pagi." $\left(\mathrm{R}^{4}\right)$

Kenyataan ini menunjukkan bahawa, remaja lebih mudah terpengaruh dengan orang yang lebih rapat dengan dirinya sehingga mereka di dominasikan oleh mereka. Elemen ini selalunya berkait rapat dengan gejala sosial yang berlaku dalam kalangan remaja. Kebiasaannya, golongan remaja yang tidak mendapat perhatian daripada ahli keluarga bakal mencari rakan sebaya yang boleh memenuhi keperluan tersebut. Remaja cenderung mengikut rakan apabila merasa keseronokan keluar bersama rakan untuk mencari hiburan. Menurut pegawai di Pusat Pemulihan Akhlak $\left(\mathrm{P}^{1}\right)$ :

"Ada batch yang terbaru, kalau ikutkan, ibu bapa tiada masalah, tapi anak yang tak ok, yang bermasalah, keluar ikut kawan, cari kebahagiaan sendiri, haa mcm tu lah. Kalau ikut secara random lah, ada yang, duduk kat kawasan Keramat, Klang, memang kawasan yang macam tu lah, yang tak membantu sangat pun, kawan-kawan dan environment pun tak sesuai” $\left(\mathrm{P}^{1}\right)$

Berdasarkan penjelasan di atas, golongan remaja sangat mudah terpengaruh dengan rakan sebaya terutama apabila mempunyai minat dan kecenderungan yang sama. Masa yang terluang lebih banyak dihabiskan bersama rakan berseronok dan berhibur. Kelalaian ibu bapa dalam memantau rakan anak-anak menyebabkan pemilihan rakan yang salah terutama di kawasan perumahan yang mempunyai persekitaran yang tidak sihat.

\subsection{Aktiviti Lumba Haram}

Aktiviti lumba haram kini bukan hanya dipelopori oleh golongan remaja lelaki, malahan pada masa ini, penglibatan remaja perempuan dalam aktiviti lumba haram semakin meningkat. Gadis yang menyertai kumpulan perlumbaan haram kebanyakannya sudah diperkosa oleh lelaki apabila terpaksa menjadi hidangan para pelumba yang memenangi satu-satu perlumbaan. Temubual bersama $\mathrm{R}^{3}$ menjelaskan; 


\begin{abstract}
"Sebenarnya saya selalu mengikuti teman lelaki saya setiap malam dan terlibat bersama-samanya dalam aktiviti lumba haram ini. Saya banyak menghabiskan masa saya dengan aktiviti ini bersamanya sahaja. Pada suatu hari, teman lelaki saya kalah dalam pertaruhan aktiviti lumba haram, jadi saya dijadikan mangsanya dan di serahkan kepada orang yang menang pada malam tersebut." $\left(\mathrm{R}^{3}\right)$
\end{abstract}

Kenyataan ini mendedahkan bahawa remaja perempuan yang terlibat dengan perlumbaan haram terdedah kepada risiko yang tinggi apabila dijadikan taruhan terhadap kekalahan teman lelaki dalam perlumbaan haram merupakan antara faktor berlakunya gejala remaja hamil tanpa nikah.

Kajian Hamjah, et. al. (2012) terhadap 50 orang remaja hamil luar nikah di dua buah pusat perlindungan wanita iaitu Pusat Bimbingan Raudhatus Sakinah dan Pertubuhan Kebajikan Darul Islah, Selangor telah mengenal pasti empat faktor yang menyumbang kepada penglibatan remaja perempuan Islam dengan seks bebas sehingga mengakibatkan kehamilan luar nikah iaitu lemah pegangan agama, menjadi mangsa penipuan, komunikasi yang lemah dengan ibu bapa serta keinginan yang kuat dari dalam diri untuk mencuba sesuatu yang baru khususnya melibatkan perkara seksual. Kajian ini mendapati faktor utama ialah kurang penghayatan keagamaan dan pengamalan agama dalam kalangan remaja perempuan Islam. Selain itu, Alavi, Nen, Ibrahim, Akhir, Mohamad dan Nordin (2012) menambah bahawa persekitaran tempat tinggal, pengaruh rakan sebaya dan pendedahan mengenai aktiviti seksual secara berleluasa dalam internet juga mempengaruhi remaja sehingga terjebak dalam hamil luar nikah.

\title{
4.8 Pil Khayal
}

Pengambilan pil khayal dalam kalangan remaja bertujuan menghilangkan tekanan. Pil khayal diambil oleh golongan remaja untuk menghilangkan tekanan masalah yang dihadapi (Norramazonizni \& Hanina, 2016). Fenomena ini berlaku apabila remaja banyak menghabiskan masa di luar rumah bersama rakan-rakan yang turut mempunyai latar belakang keluarga bermasalah sehingga terdorong melakukan tindakan-tindakan yang tidak terkawal sehingga terjebak dengan beberapa aktiviti berisiko seperti pengambilan pil khayal. Ini dinyatakan oleh $\mathrm{R}^{1}$ :

"Saya juga ada mengambil pil khayal bagi melupakan masalah. Ada masa kawan belikan dan ada masa saya membelinya sendiri." $\mathrm{R}^{1}$

Berdasarkan penjelasan di atas, disimpulkan bahawa remaja yang berada dalam keadaan ketandusan perhatian serta kasih sayang ibubapa dan keluarga lebih mudah terpengaruh dengan rakan terutama rakan sebaya yang turut mengalami masalah yang sama. Masa yang terluang banyak dihabiskan dengan aktiviti-aktiviti yang tidak berfaedah bersama-sama rakan.

\section{Kesimpulan}

Berdasarkan dapatan kajian yang dikemukakan dalam artikel ini, faktor penglibatan remaja dalam salah laku seksual sehingga hamil tanpa nikah ialah masalah dalam institusi keluarga, percintaan, menonton video dan filem porno, menjadi mangsa rogol, pengabaian terhadap 
amalan hidup beragama dan kejahilan, pengaruh rakan sebaya, aktiviti lumba haram dan pengambilan pil khayal. Ianya berlaku sama ada secara sukarela atau paksaan. Isu penglibatan dalam kalangan remaja dalam salah laku seksual ini perlu diberi perhatian dan tindakan sewajarnya oleh semua pihak. Sebaliknya jika ianya tidak ditangani segera, boleh mengakibatkan kemusnahan institusi keluarga dan membawa pelbagai masalah sosial yang lain.

Aspek pengetahuan, kefahaman dan pengamalan agama penting diberi perhatian semua pihak khususnya peranan ibu bapa dalam memberi pendidikan terhadap sesame ahli keluarga. Ibu bapa bertanggungjawab membentuk dan membimbing keluarga yang hidup dengan ajaran Islam. Pengabaian terhadap aspek ajaran agama bakal menyebabkan anak-anak meningkat remaja tanpa panduan ajaran agama. Apabila meningkat dewasa, mereka mengalami kesukaran untuk menyedari perkara yang baik dan buruk serta tidak rasa bersalah apabila melakukan perkara yang dilarang agama. Bekalan agama yang mencukupi bukan sahaja menjadi asas penting dalam proses perubahan akhlak remaja bermasalah malahan berupaya menjadi benteng pencegahan dalam diri mereka daripada segala ancaman dan cabaran dalam kehidupan terutama setelah mereka menamatkan tempoh perlindungan di Pusat Pemulihan Akhlak kelak.

\section{Rujukan}

Abdullah, S., Ghani, S. A., Akil, S. S. S. M. S., \& Faudzi, N. M. (2014). Relationship of parent and peer attachment with coping strategy among teenagers pregnancy. Procedia-Social and Behavioral Sciences, 114, 334-338.

Ahmadian, M., Hamsan, H. H., Abdullah, H., Samah, A. A., \& Noor, A. M. (2014). Risky sexual behavior among rural female adolescents in Malaysia: a limited role of protective factors. Global journal of health science, 6(3), 165.

Alavi, K., Nen, S., Ibrahim, F., Akhir, N. M., Mohamad, M. S., \& Nordin, N. M. (2012). Hamil luar nikah dalam kalangan remaja. e-BANGI, 7(1), 131-140.

Azizan, N. I., Ismail, N., Dimon, Z., \& Mohd Jabar, N. H. (2015). Permasalahan sosial di kalangan remaja di Selangor: Satu tinjauan. Prosiding International Conference on Aqidah, Dakwah and Syariah 2015 (IRSYAD2015), Kuala Lumpur, 12-13 October 2015.

Baharudin, D. F., Hamdani, S. M., Mutalib, M. M. A., \& Zakaria, M. Z. (2018). Kefahaman Beragama dan Proses Transformasi Hubungan Pasangan dalam Perkahwinan: Religion and Relationship Transformational Processes in Marriage. Al-Irsyad: Journal of Islamic and Contemporary Issues, 3(2), 75-91.

Hamjah, S. H., Samuri, M. A. A., Rasit, R. M., Sham, F. M., Kusrin, Z. M., Ismail, Z., \& Basah, N. K. (2012). Factors relating to premarital pregnancy amongst Muslim adolescents in Malaysia. Research Journal of Medical Sciences, 6(6), 266-271.

http://dwnsiswa.dbp.my/wordpress/?m=201706 (dilayari pada 1 Jun 2017).

http://mstar.com.my/berita/cerita.asp?file=/2012/9/22/mstar_berita/20120922100653\&sec=m star_berita. (Diakses pada 29 Mei 2019).

http://www.astroawani.com/berita-malaysia/4-000-remaja-bawah-18-tahun-hamil-setahun188916. (Diakses pada 29 Mei 2019).

http://www.bernama.com/bm/news.php?id=1482517

http://www.bharian.com.my/node/92792. Di akses pada 29 Mei 2019.

http://www.myhealth.gov.my/index.php/en/akibat-seks-luar-nikah. (Diakses pada 29 Mei 2019). 
http://www.myhealth.gov.my/kesan-a-akibat-kehamilan-remaja/. (Diakses pada 29 Mei 2019).

http://www.utusan.com.my/berita/nasional/seks-suka-samasuka-1.185858. (Dicapai pada 03 Februari 2016).

http://www2.esyariah.gov.my/esyariah/mal/portalv1/enakmen/State_Enact_Ori.nsf/100ae747 c72508e748256faa00188094/7b9650d84cbe7ea048257057000254e8?OpenDocument

https://www.bharian.com.my/berita/kes/2018/06/435769/dua-beradik-setan-rogol-adik-

kandung. (Diakses pada 29 Mei 2019).

https://www.dosm.gov.my/v1/uploads/files/4_Portal\%20Content/1_About\%20us/7_AnnualR eport/Laporan_Tahunan_2014_DOSM.pdf

https://www.hmetro.com.my/node/36116. (Diakses pada 10 September 2017).

https://www.hmetro.com.my/utama/2017/12/296866/update-bapa-tiri-durjana-ditahan

(Diakses pada 29 Mei 2019).

Illenia, P., \& Handadari, W. (2011). Pemulihan diri pada korban kekerasan seksual. Jurnal INSAN, 13(2).

Jasmi, K. A. (2012). Kesahan dan kebolehpercayaan dalam kajian kualitatif. Kertas kerja Kursus Penyelidikan Kualitatif Siri 1, anjuran Institut Pendidikan Guru Malaysia Kampus Temenggung Ibrahim Melaka, 28-29 Mac.

Kriyantono. R. (2006). Teknik praktis riset komunikasi. Jakarta: Kencana Prenada Media Group.

Magdalena, M. (2010). Melindungi anak dari seks bebas. Jakarta: Gramedia Widiasarana Indonesia.

Masri, S. (2005). Kaedah penyelidikan dan panduan penulisan; esei, proposal, tesis. Kuala Lumpur: Utusan Publication and Distributors.

Mohd. Fauzi, H., \& Mohd. Khairul Naim, C. N. (2012). Tinjauan kepentingan pembangunan modal insan di Malaysia (Review on the importance of human capital development in Malaysia). Jurnal Al-Tamaddun, 7(1), 75-89.

Muhammud, A. 2012. Penghuni Raudhatus Sakinah: Kajian terhadap latar belakang dan faktor salah laku. (Disertasi Sarjana Usuluddin), Universiti Malaya.

Norramazonizni, Y. \& Hanina, H. H. (2016). Kajian permasalahan tingkah laku seksual dalam kalangan belia Malaysia. International Conference on Youth (ICYOUTH) 2016, 15-17 Nov. 2016, Mines Wellness Hotel, Seri Kembangan, Selangor.

Opasawas, P. (1996). Factors affecting the sex behavior of vocational students in Chonburi Province. (Tesis Sarjana), University Chulalongkorn, Bangkok, Thailand.

Pakianathan, P. Y. (2016). Faktor-faktor yang mempengaruhi salah laku seksual dalam kalangan pelajar Sekolah Menengah. (Tesis Doktor Falsafah), Fakulti Pendidikan Dan Pembangunan Manusia, Universiti Pendidikan Sultan Idris.

Pauzi, H. M., Saim, N. J., Sarnon, N., \& Kamaluddin, M. R. (2016). Faktor-faktor pelaksanaan program pemulihan akhlak yang berkesan untuk pesalah kanak-kanak (Factors involved in implementing effective moral rehabilitation programmes for child offenders). e-Bangi, 13(3).

Saim, N. J. (2013). Social support, coping, resilience and mental health in Malaysian unwed young pregnant women and young mothers' experiences while living in a shelter home. (Tesis Kedoktoran Psikologi,) Umeå University, Sweden.

Sarnon, N., Mohamad, M. S, Fauziah, I, Alavi, K., Nen, S., Hoesni, S.M, Zaizul, R., Wan Azreena, J. (2013). Hamil luar nikah: Memahami remaja sebagai intervensi keluarga. Journal of Social Science and Humanities, 7(1), 121-130.

Suzana Jaafar, J. L. (2005). Takat keagamaan (religiosity) dan motivasi sosial seks sebelum nikah di kalangan remaja Melayu. Dlm. Roziah Omar \& Sivamurugan Pandian. Isu- 
Isu Sosial Semasa. Malaysia: Unit Penerbitan ISM, Kementerian Pembangunan Wanita, Keluarga Dan Masyarakat.

www.hmetro.com.my/mutakhir/2017/11/279818/masih-ramai-yang-berzina. (diakses pada 2 November 2017).

www.jais.gov.my/article/anak-zina-generasi-masa-depan-malaysia

Zakaria, E., Zakaria, N. F. A., Sarnon, N., \& Saim, N. J. (2017). Penerimaan mangsa rogol statutori terhadap diri sendiri dan pelaku rogol: Satu kajian kes (Statutory rape victim acceptance towards self and the perpetrator: A case study). e-Bangi, 14(5).

Zakaria, S. M., \& Zulkifli, N. A. (2017). Pengalaman remaja di rumah perlindungan dan perubahan dalam makna hidup (The experience of teens at shelter home and the changes in the meaning of life).e-Bangi, 14(5).

Zulkefli, N., \& Mustapha, Z. (2017). Remaja daripada ibu bapa yang bercerai di Malaysia: Suatu penelitian ekspresi emosi. Geografia: Malaysian Journal of Society and Space, 12(9).

\section{Biodata Penulis}

Mariam Abd. Majid, PhD, Profesor Madya di Jabatan Dakwah dan Usuluddin, Fakulti Pengajian dan Peradaban Islam, Kolej Universiti Islam Antarabangsa Selangor (KUIS). Berkelulusan Sarjana Muda Usuluddin, Sarjana Usuluddin dan Doktor Falsafah (Metodologi Dakwah) Universiti Malaya. Bidang kepakaran beliau ialah Usuluddin, Metodologi Dakwah, Psikologi Dakwah dan Pemasaran Dakwah. Beliau boleh dihubungi di alamat emel: mariam@kuis.edu.my 